\title{
SUPERNUMERARY (B) CHROMOSOMES IN POPULATIONS OF PICEA ABIES (L.) H. KARST. FROM WESTERN RHODOPES (BULGARIA)
}

Investigations on B chromosomes found for the first time for Picea abies (L.) H. Karst. have been conducted. Seeds of Picea abies from two populations of Western Rhodopes (Bulgaria) located at the southern border of species range, and protected according to Bern Convention and EC Habitat Directive were collected for this study. Mixoploidy was detected in some germinating seeds of Picea abies. It was found that metaphase cells of germinating seeds contain 0-4 B chromosomes of both metacentric and submetacentric types. The variability of $B$ chromosomes number and their occurrence was observed. Along with B chromosomes, some chromosome aberrations such as fragments and ring chromosomes were revealed in metaphase cells of Picea abies from studied populations. The possible adaptive role of $B$ chromosomes presence for Picea spp. is discussed.

Key words: Picea abies (L.) H. Karst., B chromosomes, Western Rhodopes, Bulgaria.

Introduction. Supernumerary (B) chromosomes are dispensable extra chromosomes found only in some individuals of populations from different systematical groups of plants. B chromosomes fail to pair or recombine with any $\mathrm{A}$ chromosomes in meiosis. They are often morphologically distinct, usually smaller than A chromosomes, and can show variation of their number both within one individual and between individuals [1]. B chromosomes are most widespread among conifers of genus Picea. Presently B chromosomes were revealed in 14 species of Picea A. Dietr. [2]. Initially, B chromosomes were discovered in Picea obovata Ledeb. and Picea sitchensis (Bong.) Carr. [3, 4]. B chromosomes and their occurrence are well studied in different provenances of Picea obovata [3, 5-9]. In spite of detailed earlier karyological studying B chromosomes were not detected in the closely-related Picea abies (L.) H. Karst. to date [10-15], though they were found in populations of interior spruce Picea $\times$ $\times$ fennica (Regel) Kom., growing in the introgression zone between Picea obovata and Picea abies [16]. The objective of this study was to analyze

(C) A.N. TASHEV, T.S. SEDEL'NIKOVA, A.V. PIMENOV, 2014

B chromosomes found for the first time in Picea abies in two populations from Western Rhodopes (Bulgaria).

Materials and methods. Picea abies (Norway spruce) grows in Middle Europe from the Western Alps to Baltic countries, the Ukrainian Carpathians and south-western regions of Russia to the east, and from the northern part of Scandinavian Peninsula to the Rhodopes in the south [17]. Natural spruce forests in Bulgaria occupy about 75000 ha. Their location is related, mainly, to the Rila-Rhodope mountain region where they play an important ecological and economic role [18]. The Rila-Rhodope region is the southern border of natural Picea abies range. It is known that Picea abies forests on the Balkan Peninsula are of very ancient origin [19]. According to Fukarek [20] and Alexandrov [21] the species growing in the mountains of Balkan Peninsula is more polymorphic in comparison with the other parts of its range, which could be due to the fact that the populations here remained almost unaffected by the last glaciations.

First of the studied population of Picea abi-

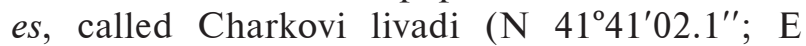
$\left.23^{\circ} 53^{\prime} 56.2^{\prime \prime}\right)$, is situated on the territory of Garmen State Forest Service, close to the village Kovachevitza. Characteristics of site conditions: $1400 \mathrm{~m}$ a.s.1., north-western exposition, upper part of a slope. $18^{\circ}$ inclination; soil: Eutric Cambisols, rich, fresh to wet, $61-120 \mathrm{~cm}$ deep, slightly stony, sandy; bedrock: gneiss. Stand composition: First layer: Picea abies (L.) Karst. - (80\%, age - 120 years; height $28 \mathrm{~m}$, diameter at breast height $(\mathrm{DBH})$ $42 \mathrm{~cm}$, density 0.5 , site class 2 , growing stock $291 \mathrm{~m}^{3}$ per hectare; Pinus sylvestris L. - $20 \%$, age 120 years, height $28 \mathrm{~m}, \mathrm{DBH} 46 \mathrm{~cm}$, density 0.5 , site class 2; single individuals of Abies alba Mill. age 120 years, height $28 \mathrm{~m}, \mathrm{DBH} 42 \mathrm{~cm}$, density 0.5 , site class 2; Fagus sylvatica L. - age 120 years, height $28 \mathrm{~m}, \mathrm{DBH} 42 \mathrm{~cm}$, density 0.5 , site class 2 . Second layer - undergrowth: $P$. abies $-100 \%$, age 30 years, height $6 \mathrm{~m}$, DBH $6 \mathrm{~cm}$, density 0.6 , site 
class 2, single individuals of $A$. alba - age 30 years, height $6 \mathrm{~m}$, DBH $6 \mathrm{~cm}$, density 0.6 , site class $2 ; F$. sylvatica - age 30 years, height $6 \mathrm{~m}, \mathrm{DBH} 6 \mathrm{~cm}$, density 0.6 , site class 2 .

The second studied population called Drangov kamak (N 41 $53^{\prime} 04.0^{\prime \prime}$; E 2346 $56.1^{\prime \prime}$ ), is situated on the territory of Eleshnitza State Forest Service, near the village of Zlataritza. Characteristics of site conditions: 1550 a.s.l., northern exposition, lower part of a slope, $21^{\circ}$ inclination; soil: (Eutric Cambisols), rich, wet, depth $61-120 \mathrm{~cm}$, slightly stony, clayey; bedrock: South Bulgarian granite. Stand composition: First layer: $P$. abies - $40 \%$, age 140 years, height $31 \mathrm{~m}, \mathrm{DBH} 40 \mathrm{~cm}$, density 0.5 , site class 2 , growing stock $171 \mathrm{~m}^{3}$ per hectare; $P$. sylvestris $60 \%$, age 140 years; height $31 \mathrm{~m}, \mathrm{DBH} 40 \mathrm{~cm}$, density 0.5 , site class 2 ; single individuals of $A$. alba - age 140 years. Second layer - undergrowth: $P$. abies $90 \%$, age 70 years, height $20 \mathrm{~m}$, DBH $20 \mathrm{~cm}$, density 0.3 , site class $2 ; P$. sylvestris $-10 \%$, age 70 years, height $21 \mathrm{~m}$, site class 2; single individuals of $A$. alba undergrowth. Third layer - undergrowth: $P$. abies $80 \%$, age 30 years, height $7 \mathrm{~m}, \mathrm{DBH} 6 \mathrm{~cm}$, density 0.3 ; P. sylvestris $-20 \%$, age 30 years, height $9 \mathrm{~m}$, diameter $10 \mathrm{~cm}$; single individuals of $A$. alba undergrowth. Fourth layer - undergrowth: P. abies $-80 \%$, age 10 years, height $1 \mathrm{~m}$, DBH $6 \mathrm{~cm}$, density $0.3 ; P$. sylvestris $-20 \%$, age 10 years, height $2 \mathrm{~m}$.

Both stands are natural, of seed origin and have a special status of seed production stands, which was crucial factor for their conservation to date. Natural habitats of the stands are included in the new edition of Red Data Book of Bulgaria, vol. 3 - Natural habitats (http://e-ecodb.bas.bg/rdb/bg/) - Spruce forests (34G3) - EUNIS: G3.1E Southern European [Picea abies] forests; PAL. CLASS.: 42.24 Southern European Norway spruce forests; HD 92/43: 9410 Acidophyllous Picea forests of the mountain to alpine levels (Vaccinio-Piceetea); category «potentially endangered» [NT - A1, 2 B1 C3 D1 E1 F1 G1 H1 I L3]. The stands are situated also on the territory of protected zone within the framework of European ecological network NATURA 2000 - code BG 0001030 Western Rhodopes. These habitats are protected according to Biodiversity Act of Bulgaria $(2002,2007)$ and are included in Appendix 1 of the Act. They are protected also according to Bern Convention (1973) and EC Habitat Directive.

Seeds of Picea abies from two populations Charkovi livadi and Drangov kamak were collected. The seeds were germinated on water-moistened filter paper at $24{ }^{\circ} \mathrm{C}$. Germs with $1-2 \mathrm{~cm}$ roots were pretreated by $1 \%$ colchicine solution for $4-6 \mathrm{~h}$ at $24{ }^{\circ} \mathrm{C}$, fixed in a mixture of absolute ethanol/glacial acetic acid $(3: 1)$, and stored at $-20{ }^{\circ} \mathrm{C}$. The samples were stained with $1 \%$ aceto-hematoxylin. Root tip meristem cells were used for the study. After staining the root tips were squashed in a drop of $60 \%$ chloral hydrate solution. The metaphase plates were examined and photographed in oil immersion using the Zeiss Axiostar-plus microscope. Chromosomes were studied in metaphase cells presenting the complete chromosome set.

Results and discussion. Diploid set of 24 (A) chromosomes $(2 n=2 x=24)$ was found in root meristems of Picea abies from the two populations studied. The data confirm the results of previous studies on the chromosome numbers of Picea abies from other populations of Bulgaria [22, 23]. Diploid chromosome number $2 n=24$ was found in different parts of the species' distributions, like Estonia, Lithuania, Romania, Czech Republic and Canada $[5,10,11,13]$.

Mixoploidy was found in some germinating seeds both from Drangov kamak and Charkovi livadi populations: in separate metaphase cells triploid $(2 n=$ $=3 x=36)$ and tetraploid $(2 n=4 x=48)$ chromosome

Variability of chromosome numbers in germinating seeds of Picea abies from Western Rhodopes (Bulgaria)

\begin{tabular}{l|c|c}
\hline \multirow{2}{*}{ Chromosome set } & \multicolumn{2}{c}{$\begin{array}{c}\text { Germinating seeds } \\
\text { (number/\%) }\end{array}$} \\
\cline { 2 - 3 } & $\begin{array}{c}\text { Charkovi } \\
\text { livadi }\end{array}$ & $\begin{array}{c}\text { Drangov } \\
\text { kamak }\end{array}$ \\
\hline $2 n=24$ & $6 / 19.8$ & $9 / 59.8$ \\
$2 n=24 ; 24+1 \mathrm{~B}$ & $1 / 3.3$ & - \\
$2 n=24+1 \mathrm{~B}$ & $8 / 27.4$ & $2 / 13.4$ \\
$2 n=24+2 \mathrm{~B}$ & $2 / 6.6$ & - \\
$2 n=24+1 \mathrm{~B} ; 24+2 \mathrm{~B}$ & $2 / 6.6$ & $1 / 6.7$ \\
$2 n=24+1 \mathrm{~B} ; 24+3 \mathrm{~B}$ & $1 / 3.3$ & - \\
$2 n=24+2 \mathrm{~B} ; 24+4 \mathrm{~B}$ & $1 / 3.3$ & - \\
$2 n=24+1 \mathrm{~B} ; 24+2 \mathrm{~B} ;$ & $1 / 3.3$ & - \\
$24+4 \mathrm{~B}$ & & - \\
$2 n=24+1 \mathrm{~B} ; 24 ; 36$ & $2 / 6.6$ & - \\
$2 n=24+1 \mathrm{~B} ; 48$ & $2 / 6.6$ & $2 / 13.4$ \\
$2 n=24 ; 48$ & $3 / 9.9$ & $1 / 6.7$ \\
$2 n=24 ; 36 ; 48$ & $1 / 3.3$ & $15 / 100$ \\
Sum total & $30 / 100$ & \\
\hline
\end{tabular}



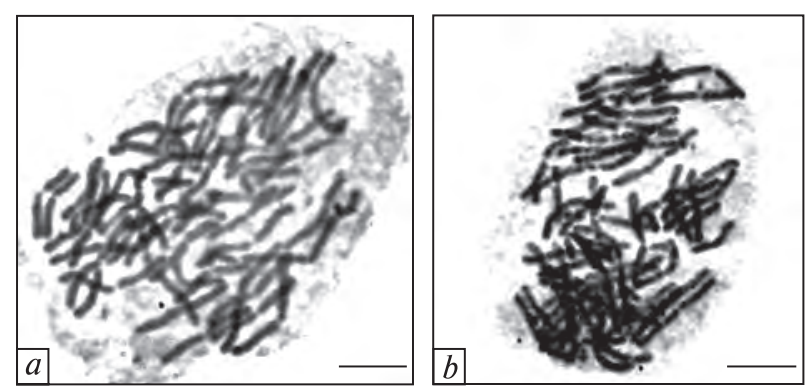

Fig. 1. Metaphase plates of Picea abies with tetraploid chromosome number $(2 n=4 x=48)$ in populations Drangov kamak $(a)$ and Charkovi livadi $(b)$. Bar $=10 \mu \mathrm{m}$

numbers were revealed (Table, Fig. 1), while the majority of cells had diploid chromosome number $(2 n=$ $=2 x=24)$. Earlier, the presence of mixoploids was reported for Picea abies populations from Sweden, Czech Republic and France [14, 15, 24].

B chromosomes were found in the metaphase cells in both Picea abies populations. The absolute length of B chromosomes was about $20-30 \%$ of A-chromosome length. Simultaneously, the triploid and tetraploid cells were observed in some root tips, which contained B chromosomes. Supernumerary chromosomes of Picea spp. are subdivided into two types according to their centromere position: the more common (B1) type is metacentric, the other one (B2) is submetacentric [25]. B chromosomes from studied populations of Picea abies belonged to either B1 and B2 types (Fig. 2, $a, b$ ). Therewith among germinating seeds with supernumerary chromosomes B1 type from Charkovi livadi was found in $93.3 \%$ of cases, and from Drangov kamak - in $86.7 \%$ of cases. The other cells with supernumerary chromosomes contained B2 type.

The results of analysis of $\mathrm{B}$ chromosome number and their occurrence in Picea abies are summarized in the Table. B chromosomes presence and their number were unstable in germinating seeds from both populations of Picea abies. The seeds from Charkovi livadi contained 0-4 B chromosomes, while these from Drangov kamak had 0-2 B chromosomes (Fig. 2, $a-g$ ). Presence and occurrence of $\mathrm{B}$ chromosomes greatly varied among seeds from the two populations of Picea abies. Increase of the number and occurrence of $\mathrm{B}$ chromosomes and their maximum presence was observed in the population Charkovi livadi (Table).

In both populations of Picea abies, particularly in Charkovi livadi, B chromosome number varied in one and the same germinating seed (Table, Fig. $2, h)$. In previous studies on different Picea species presence of constant B chromosome number for each individual was observed. Most often they had been found in all the cells, but could be observed only in some of them [3-5, 7, 13, 26-28].

The results of distribution of metaphase cells in number of chromosomes in them in studied Picea abies provenances are presented in Fig. 4. Among cells possessing $\mathrm{B}$ chromosomes cells with $1 \mathrm{~B}$ chromosome were found more frequently, cells with $2 \mathrm{~B}$ chromosomes were found seldom, and cells with 3-4B chromosomes were found most rarely.

According to other studies, the highest number of B chromosomes in spruce species is found in Picea glauca (Moench) Voss (1-6B), Picea glehnii (Fr. Schmidt) Mast. and Picea sitchensis (1-5B), and also in Picea obovata $(1-4 \mathrm{~B})$, but the individuals with more than one or two B chromosomes were met, as a rule, seldom $[3,8,25,28-30]$. This trend may be due to the unfavourable effects of the high number of B chromosomes. For example, low pollen fertility was revealed in Picea obovata individuals with 3-4B chromosomes [31]. In Picea sitchensis, as the number of B chromosomes increases, a progressive slowdown of female flowering was observed [30]. At the same time, the availability of B chromosomes may play some positive role. According to some studies the process of seed germination was accelerated in Picea glauca and Picea obovata with B chromosomes [8, 25]. As for Picea abies from Charkovi livadi and Drangov kamak, the seeds with B chromosomes germinated 3-4 days earlier than these without B chromosomes.

Variability of B chromosomes number and their occurrence owing to their provenance, accumulation mechanisms and adaptive role in plant populations, including conifers, have been discussed in some reviews [1, 27, 32, 33]. B chromosomes of plants have an irregular and non-Mendelian way of inheritance. The variability of B chromosome number in populations of conifers is regulated by accumulation and elimination which proceed at formation of reproductive structures. Study of inheritance of supernumerary chromosomes in Picea obovata with different numbers of B chromosomes at open pollination has shown their transmission to the progeny both in male and female lines [27, 31]. The controlled cross performed among Picea 

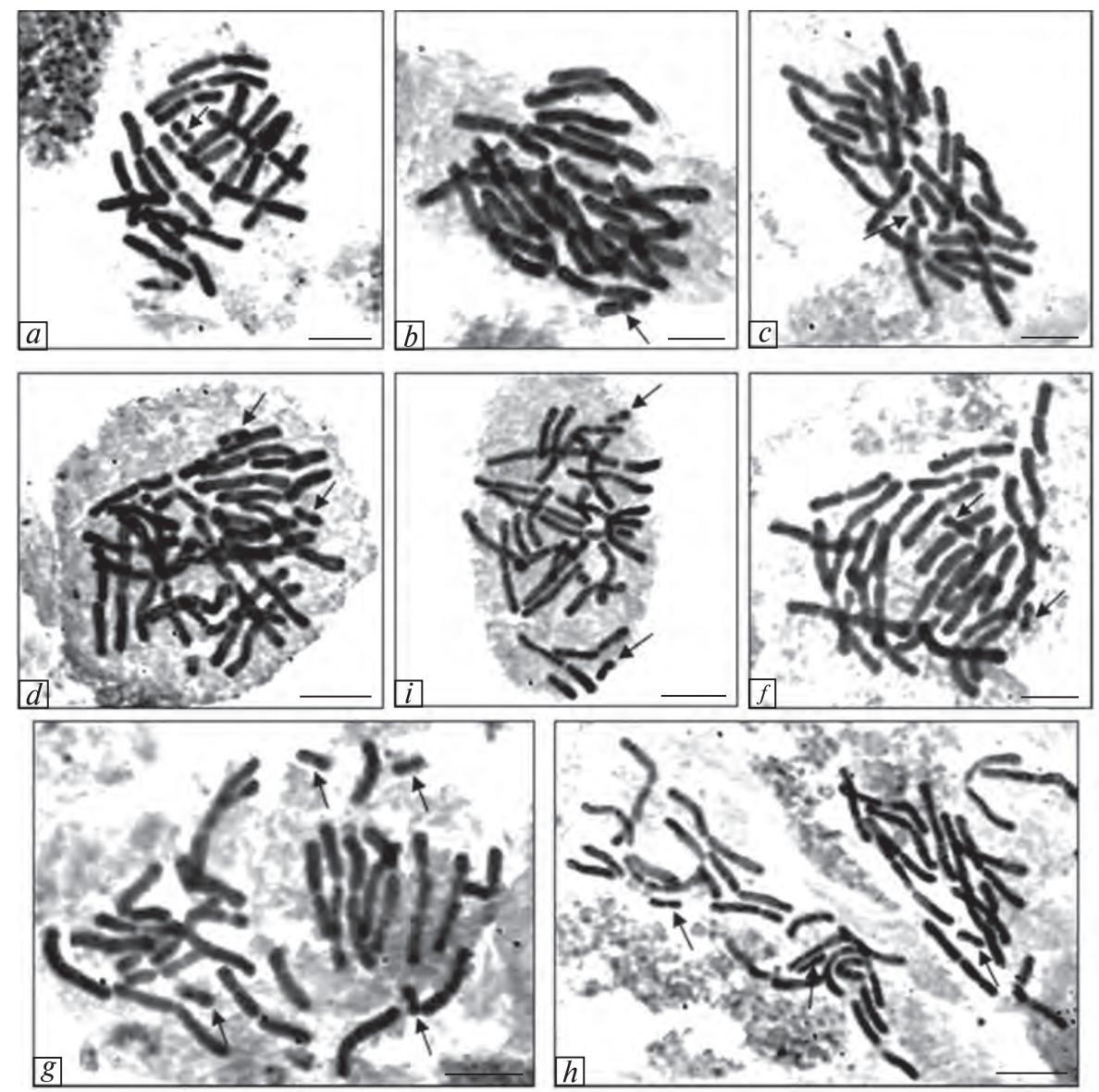

Fig. 2. Metaphase plates with B chromosomes in Picea abies from Drangov kamak and Charkovi livadi: $a-$ B chromosome of metacentric (B1) type $(2 n=24+1 \mathrm{~B}) ; b, c-\mathrm{B}$ chromosomes of submetacentric (B2) type $(2 n=$ $=24+1 \mathrm{~B}) ; d-f-2 n=24+2 \mathrm{~B} ; g-2 n=24+4 \mathrm{~B} ; h-$ variability of $\mathrm{B}$ chromosome number within germinating seed $(2 n=24+1 \mathrm{~B} ; 2 n=24+2 \mathrm{~B})$. B chromosomes are shown by arrows. Bar $=10 \mu \mathrm{m}$

sitchensis with known B-constitution has shown that the transmission of B chromosomes to the progeny is determined by their distribution between the male and female parents. The «accumulative» behaviour of B chromosomes may vary in the male and female lines depending on the actually existing number of B chromosomes [30].

B chromosomes probably can impact the adaptive potential of individuals, which is shown by increase of genome variability level and also by increase of population polymorphism [32, 34]. Picea populations with variable number of B chromosomes are genetically more polymorphic. Emergence of B chromosomes increases DNA amount in the nuclear genome [1]. According to Teoh et al. [25], one B chromosome increases DNA amount by $2.7 \%$ in Picea glauca. As a whole, the trend of increasing the nuclear DNA amount in plants under unfavourable environmental conditions has been revealed for conifers [35-37].

The information accumulated so far shows that B chromosomes distribution and occurrence are related to fluctuations of environmental factors for all species of Picea genus. It was established that the northern border of B chromosomes distribution of Picea sitchensis in the North America coincides with the permafrost line, and the highest B chromosomes occurrence is found in the regions with minimum precipitation and high summer insolation [29]. Decrease of B chromosomes occurrence of Picea glauca was observed from the east to the west in regions of North America. Such variability is considered as adaptive one and as a reason of different mortality of plants with 

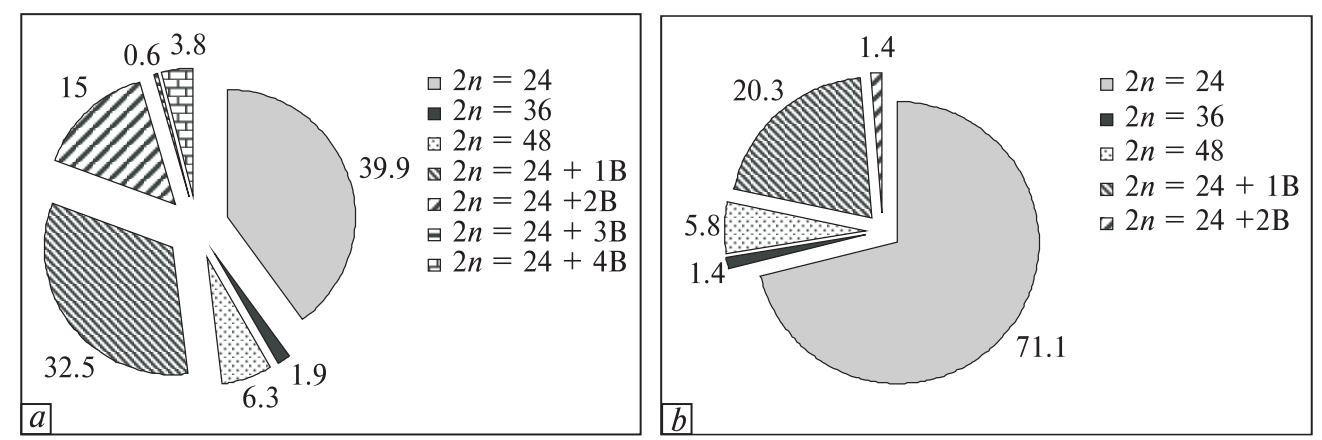

Fig. 3. Distribution of metaphase cells in number of chromosomes in germinating seeds of Picea abies: $a$ - population Charkovi livadi, $b$ - population Drangov kamak
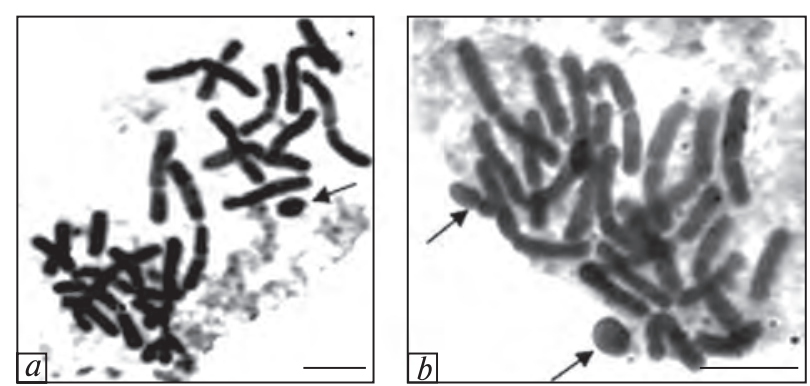

Fig. 4. Chromosome mutations in Picea abies from Charkovi livadi and Drangov kamak: $a$ - part of metaphase plate with fragment; $b$ - part of metaphase plate with acentric ring and $\mathrm{B}$ chromosome. Mutations and $\mathrm{B}$ chromosome are shown by arrows. Bar $=10 \mu \mathrm{m}$

and without B chromosomes under specific environmental conditions [25]. Maximum occurrence and the highest number of B chromosomes was observed in Picea obovata populations from the eastern part of the range, particularly in regions with severe climate of Central and East Siberia. In many cases B chromosomes appearance in Picea obovata populations was related to the extreme growing conditions [8, 9, 27].

Probably B chromosomes occurrence in marginal Picea abies populations from Charkovi livadi and Drangov kamak growing at the southern border of species range is connected with adaptation of plants to the environmental conditions. A serious factor for induction of B chromosomes could be the fact that the region of study was subjected to substantial anthropogenic pressure due to uranium extraction industry and natural radioactivity background. The studies performed in the period 1993-2011 have shown that there is increased concentrations of radionuclides U238 and Ra226 in the soils and raised beta-activity, an emanation of Rn222, resulting from the outfalls of mining activity and the rocks making the surrounding hills [38-40].

Somechromosome mutations have been revealed in metaphase Picea abies cells from both studied populations. They are presented by fragments and ring chromosomes (Fig. 4). Occurrence of chromosome mutations in spruce seeds from Charkovi livadi was 3,6 \%, and from Drangov kamak $8,0 \%$. Chromosome mutations were found in Picea obovata, Picea ajanensis (Lindl. et Gord.) Fisch. ex Carr., Picea glehnii, Picea shrenkiana Fisch. et C.A. Mey. Occurrence of mutations in Picea populations increases under extreme environmental conditions. It was established that irregularities in mitosis in Picea obovata with B chromosomes are found more often [7-9, 28, 41]. A high percent of chromosome mutations in Picea abies from Charkovi livadi and Drangov kamak populations may be due to their location at the border of species range and unfavorable environmental factors as well as B chromosomes occurrence.

So, presence of B chromosomes in Picea $a b$ ies populations in the Western Rhodopes indicates their further extension among Picea ssp. and their possible adaptive role. The revealed $\mathrm{B}$ chromosomes in Picea abies from Western Rhodopes (Drangov kamak and Charkovi livadi) confirms the high nature protection status of these unique natural spruce stand included in the Red Data Book of Bulgaria and protected by the Bern convention.

We thank Dr. Peter Zhelev for the critical reading and valuable comments on an earlier draft of the manuscript. 
Supernumerary (B) chromosomes in populations of Picea abies (L.) H. Karst.

А.Н. Тамев, Т.С. Седельникова, А.В. Пименов

ДОБАВОЧНЫЕ (В) ХРОМОСОМЫ

В ПОПУЛЯЦИЯХ PICEA ABIES (L.) H. KARST. ИЗ ГОРНОГО МАССИВА ЗАПАДНЫЕ РОДОПЫ (БОЛГАРИЯ)

Проведено исследование В-хромосом, обнаруженных впервые у вида Picea abies (L.) H. Karst. Для настоящего исследования семена собраны из двух популяций Picea abies в Западных Родопах (Болгария), расположенных на южной границе видового ареала и охраняемых в соответствии с Бернской конвенцией и Директивой ЕС о местообитаниях. В отдельных проростках семян Picea abies найдена миксоплоидия. Обнаружено, что метафазные клетки проростков семян из изученных популяций Picea abies содержат 0-4 В-хромосомы как метацентрического, так и субметацентрического типов. Наблюдается изменчивость числа В-хромосом и их появления. Наряду с В-хромосомами в метафазных клетках $P i$ cea abies выявлены хромосомные мутации - фрагменты и кольцевые хромосомы. Обсуждается возможная адаптивная роль присутствия В-хромосом у видов Picea.

\section{О.М. Ташев, Т.С. Седельникова, О.В. Піменов}

\section{ДОДАТКОВІ (В) ХРОМОСОМИ}

У ПОПУЛЯЦІЯХ PICEA ABIES (L.) H. KARST. ІЗ ЗАХІДНИХ РОДОПІВ (БОЛГАРІЯ)

Проведено дослідження В-хромосом, виявлених вперше у виду Picea abies (L.) H. Karst. Для даного дослідження насіння зібране 3 двох популяцій Picea abies в Західних Родопах (Болгарія), що розташовані на південному кордоні видового ареалу та охороняються відповідно до Бернської конвенції та Директивою $\mathrm{EC} \mathrm{про} \mathrm{місце} \mathrm{розповсюдження.} \mathrm{В} \mathrm{окремих}$ проростках насіння Picea abies знайдено міксоплоїдію. Виявлено, що метафазні клітини проростків насіння з вивчених популяцій Picea abies містять 0-4 В-хромосоми як метацентричного, так і субметацентричного типів. Спостерігається мінливість числа В-хромосом. Поряд з В-хромосомами у метафазних клітинах Picea abies виявлено хромосомні мутаціїфрагменти та кільцеві хромосоми. Обговорюється можлива адаптивна роль присутності В-хромосом у видів Рісеа.

\section{REFERENCES}

1. Jones R.N. B chromosomes in plants // New Phytol. 1995. - 131. - P. 411-434.

2. Муратова Е.Н. Хромосомные числа голосеменных растений Pinaceae (Picea-Pinus) // Бот. журн. 2011. - 96, № 10. - C. 1389-1404.

3. Круклис М.В. Добавочные хромосомы у голо- семенных (на примере Picea obovata Ldb.) // Докл. AH CCCP. - 1971. - 196, № 5. - C. 1213-1216.

4. Moir R.B., Fox D.P. Supernumerary chromosomes in Picea sitchensis (Bong.) Carr. // Silvae Genet. 1972. - 21, № 5. - P. 182-186.

5. Pravdin L.F., Abaturova G.A., Shershukova O.P. Karyological analysis of European and Siberian spruce and their hybrids in the USSR // Silvae Genet. 1976. - 25, № 3/4. - P. 89-95.

6. Herzog $S$. Investigations on chromosomes of Siberian spruce (Picea obovata Ledeb.) // Silvae Genet. 1987. - 36, № 1. - P. 42-44.

7. Muratova E.N., Sedelnikova T.S. Karyotypic variability and anomalies in populations of conifers from Siberia and the Far East // Cytogenetic Studies of Forest Trees and Shrubs - Review, Present Status, and Outlook on the Future / Eds H. Guttenberger et al. - Zloven : Arbora Publ., 2000. - P. 129141.

8. Муратова Е.Н., Владимирова О.С. Добавочные хромосомы кариотипа ели сибирской $P$. obovata // Цитология и генетика. - 2001. - 35, № 4. С. $38-44$.

9. Седельникова Т.С., Муратова Е.Н., Пименов А.В., Ефремов С.П. Кариологические особенности болотных и суходольных популяций Picea obovata в Западной Сибири // Бот. журн. - 2004. - 89, № 5. - С. $718-733$.

10. Terasmaa T. Karyotype analysis of Norway spruce Picea abies (L.) Karst. // Silvae Genet. - 1971. - 20, № $5 / 6$. - P. 179-182.

11. Габрилавичюс Р.Б. Кариологическое исследование ели обыкновенной в Литовской ССР // Лесоведение. - 1972. - № 2. - С. 76-78.

12. Papes D., Jelenic S., Cerbah M., Yakovlev S.S. Fluorescent chromosomal banding in Picea omorica and Picea abies // Studies of Forest Trees and Shrub Species : Proc. $1^{\text {st }}$ IUFRO Cytogenet. Work. Cytogenetic - Zagreb, 1997. - P. 103-109.

13. Nkongolo K.K. RAPD and cytological analyses of Picea ssp. from different provenances: genomic relationships among taxa // Hereditas. - 1999. - 130, № 2. - P. 137-144.

14. Седельникова Т.С., Пименов А.В., Вараксин Г.С., Янковска В. Числа хромосом некоторых видов хвойных // Бот. журн. - 2005. - 90, № 10. - С. 16111612.

15. Седельникова Т.С., Пименов А.В., Онучин А.А., Янковска В. Числа хромосом некоторых видов хвойных в дендрариях и парковых насаждениях // Бот. журн. - 2008. - 93, № 1. - С. 157-158.

16. Фарукшина Г.Г., Путенихин В.П., Бахтиярова Р.М. Кариотипическая изменчивость ели сибирской на Южном Урале // Лесоведение. - 1997. - № 2. C. $78-84$. 
17. Бобров Е.Г. Лесообразующие хвойные СССР. Л.: Наука, 1978. - 180 с.

18. Александров А., Попов П. Фенотипическое положение ели в Рило-Родопском районе Болгарии в видовом комплексе ели европейской и сибирской // Наука за гората. - 2009.- Кн. 2. - С. 3-18.

19. Правдин Л.Ф. Ель европейская и ель сибирская в СССР. - М.: Наука, 1975. - 176 с.

20. Fukarek $P$. Die Fichte und die Fichtenwälder an ihren südlichen Arealgrenzen in der Balkanländer. Rad. Akad. nauka i umjetn. BiH. Od. Prirod. I mat. Nauka. Saraevo. - 1970. - 39, № I. - P. 147174.

21. Александров A.X. Изменчивость ели (Picea abies (L.) Karst.) в Болгарии по форме семенных чешуй // Forest Sci. - 1984. - 21, № 6. - C. 3-11.

22. Ivanova D., Vladimirov V., Stanimirova $P$. // Reports (1445-1456). Mediterranean chromosome number reports / Eds G. Kamari et al. - 2005. - 15. - P. 719.

23. Petrova A., Zieliński J., Natcheva R. // Reports (15841603). Mediterranean chromosome number reports / Eds G. Kamari et al. - 2006. - 16. - P. 431-442.

24. Kiellander C.L. Polyploidy in Picea abies // Hereditas. 1950. - 36, № 3. - P. 513-516.

25. Teoh S.B., Rees H. B-chromosomes in white spruce // Proc. Roy. Soc. London. - 1977. - 198, N 1133. P. 325-344.

26. Hizume M., Kishimoto K., Tominaga K., Tanaka A. Presence of B-chromosome in Picea glehnii (Pinaceae) // Kromosomo. - 1988. - 2, № 51/52. - P. 1715-1720.

27. Муратова Е.Н. В-хромосомы голосеменных // Усп. соврем. биологии. -2000 . - 120, № 5. - С. 452465.

28. Муратова Е.Н., Владимирова О.С. Добавочные хромосомы у Picea glehnii (Pinaceae) // Бот. журн. 2001. - 86, № 5. - C. 125-130.

29. Moir R.B., Fox D.P. Supernumerary chromosome distribution in provenances of Picea sitchensis (Bong.) Carr. // Silvae Genet. - 1977. - 26, № 1. - P. 26-33.

30. Kean V.M., Fox D.P., Faulkner R. The accumulation mechanism of the supernumerary (B-) chromosome in Picea sitchensis (Bong.) Carr. and the effect of this chromosome on male and female flowering // Silvae Genet. - 1982. - 31, № 4. - P. 126-131.

31. Брока М.В. В-хромосомный полиморфизм в при- родных популяциях Picea obovata Ledeb. // Роль селекции в улучшении латвийских лесов. - Рига, 1990. - С. 105-117.

32. Кунах B.A. Додаткові або В-хромосоми рослин. Походження і біологічне значення // Вісн. Укр. т-ва генетиків і селекціонерів. - 2010. - 8, № 1. C. $99-139$.

33. Седельникова Т.С., Муратова Е.Н., Пименов А.В. Изменчивость хромосомных чисел голосеменных растений // Усп. соврем. биологии. - 2010. 130, № 6. - С. 557-568.

34. Борисов Ю.М. Горный Алтай - место взрывной эволюции В-хромосом // Природа. - 2012. № 5. - C. 10-19.

35. Wakamiya I., Newton R.J., Johnston J.S., Price H.J. Genome size and environmental factors in the genus Pinus // Amer. J. Bot. - 1993. - 80. - P. 1235-1241.

36. Murray B.G. Nuclear DNA amounts in gymnosperms // Ann. Bot. - 1998. - 82. - P. 3-15.

37. Ahuja M.R., Neale D.B. Evolution of genome size in conifers // Silvae Genet. - 2005. - 54, № 3. - P. 126137.

38. Nikolov P., Petrova R., Pressyanov D. et al. Research on a biological restoration of technologically contaminated areas: MDP «Drouzba» - Eleshnisa. Institute of Nuclear Research and Nuclear Energy. Contract № 1560/1993, Final Report to the Bulgarian Ministry of Environment. - 1993.

39. Петрова P., Николов П. Почвени и радиоекологични проучвания в района на село Елещница във връзка с рекултивацията на насипища от уранодобивната промишленост // Наука за гората. - 1994. - № 2. - С. 47-57.

40. Табаков Б., Петрова Р., Колев Е., Фивек М. Оценка на екологичния риск - основно средство при избор на решения за опазване на околната среда при управление на минните отпадъци // Ecology Problems in Mineral Raw - Material Branch Proc. Int. Sci. Techn. Conf. (28 Aug.-1 Sept. 2011). Varna, 2011. - P. 201-208.

41. Карпюк Т.В., Муратова Е.Н., Владимирова О.С., Седельникова Т.С. Кариологический анализ ели Шренка // Лесоведение. - 2009. - № 1. - С. 52-58.

Received 16.07.13 